\title{
STUDIES ON JAPANESE CTENOSTOMATOUS BRYOZOA, I - ON SOME SPECIES OF CARNOSA-
}

$\operatorname{AUTHOR}(\mathrm{S})$ :

Mawatari, Shizuo

CITATION:

Mawatari, ShizUo. STUDIES ON JAPANESE CTENOSTOMATOUS BRYOZOA, I -ON SOME SPECIES OF CARNOSA-. PUBLICATIONS OF THE SETO MARINE BIOLOGICAL LABORATORY 1953, 3(2): 213-220

ISSUE DATE:

1953-12-20

URL:

http://hdl.handle.net/2433/174467

RIGHT: 


\title{
STUDIES ON JAPANESE CTENOSTOMATOUS BRYOZOA, I ON SOME SPECIES OF CARNOSA ${ }^{122}$ )
}

\author{
SHIZUO MAWATARI \\ Research Institute for Natural Resources, Tokyo
}

With Plates $X-X I I$ and 3 Text-figures

Our knowledge on the Ctenostomata in the north-western Pacific remains yet considerably insufficient. Only 4 Ctenostomata had been recorded from Japan and adjacent seas until Dr. Lars SILÉN (1942) published a paper on Carnosa and Stolonifera collected by Sixten Bock's expedition to Japan and the Bonin Islands dealing with 14 different species.

So far as I am aware, the first study on Japanese specimens, though has not been published, seems to be attempted by Dr. Alyce RoBERTson of the University of California on the materials sent by the late Dr. Asajiro OKa. In her letter to Dr. OKA, I have found a list of species she identified. Alcyonidium gelatinosum is only one Carnosa seen in the list.

In 1925 Dr. Yaichiro OKADA published a detailed description on a curious new species of Alcyonidium proposing a new subgeneric name Paralcyonidium. Al. (Paral.) vermiculare is quite distinct in its extremely long, string-like or worm-like body.

In 1933 Dr. OkADA reported Alcyonidium gelatinosum from Northern Kurile Islands, and in 1942 Silén added 6 species of Alcyonidium and 1 species of Bockiella.

Among numerous specimens of bryozoans collected by the Biological Laboratory of the Imperial Household, I have found some beautiful Carnosa apparently new to science. The following is the first result of a series of my studies on Japanese Ctenostomata.

Here I express my cordial thanks to Dr. Hirotaro HATTORI, of the Biological Laboratory of the Imperial Household for his kindness in placing valuable materials of the Laboratory at my disposal. I am also greatly indebted to Dr. Katsuzo KuRonuma who kindly gave me materials from Northern Kurile Islands, and to Dr. Lars SILÉN and Dr. Folke Borg in Sweden who helped me in giving their valuable papers.

1) Contributions from the Seto Marine Biological Laboratory, No. 219.

2) Contributions from the Research Institute for Natural Resources, No. 653.

Publ. Seto Mar. Biol. Lab,, III (2), 1953. (Article 20) 


\section{Alcyonidium erectum SILEN 1942}

(Pl. X, Figs. 1-2, Pl. XI, Fig. 7 ; Text-fig. $1 \mathrm{~A}-\mathrm{B}$ )

Alcyonidium erectum SILÉN, 1942, Ark. f. Zool., 34A, 8, p. 11, text-figs. 3, 4.

Zoarium: The zoarium is bilaminar, thin and semitransparent, brownish in spirit but recorded by the collector as milky white in fresh materials. The basal end of the colony spreading over the substratum. The branches are somewhat irregular, but usually of the form of narrow braid, sometimes anastomosing. In living state, the conspicuously soft and flexible body seems to sway to and fro in the wave.

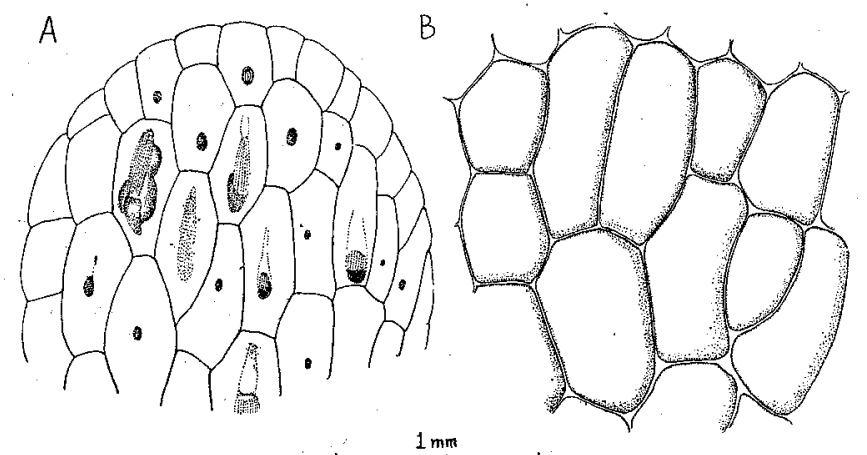

Fig. 1. Alcyonidium erectum SILEN. A. Growing margin of a semitransparent branch. B. Older part of a colony.

Zooecium: The zooecia, arranged in many longitudinal rows, are rather regularly quadrangular or elongate hexagonal in shape. The frontal walls are extremely thin and much transparent that the zooecia of the posterior layer are clearly visible through the anterior layer. The separating walls are thin and a little depressed frontally. The frontal surface is convex, and entirely smooth, with no projections of any kind. The aperture is placed close to the distal end of the zooecium, but difficult to distinguish in the surface view by the fact that there is neither projection nor coloured fold near the orifice. It is only distinguished by the position of the polypide.

Polypide: The polypide is slender, light brown in colour. The vestibule is elongated, extending halfway to the basal wall. The tentacle sheath is slender, going obliquely downwards and then horizontally backwards to the proximal end of the zooecium. The tentacles appeared 22 in number in my cross-sectioned preparations.

The pharynx passes into the slender stomach without distinct depression. The coecum and the intestine are small.

Remarks: The specimen in hand closely agrees with the description and figures of SILÉN, who had only a torn off top end of zoarium. As he has stated, the present 
species is not identical with any other known species especially by its branched, thin colony and extremely smooth frontal wall. SILÉN wisely separated this species from his Alcyonidium foliaceum in its transparency and absence of kenozooids. The form of the zoarium is, as he has imagined, quite distinct from that of Al. foliaceum.

Specimen examined: No. 7626 (Biological Laboratory, Imperial Household Coll. Bry. No. 80) About 2 miles south of Jôgashima, Kanagawa Prefecture, 70 fathoms. July 22, 1935. A complete colony attached to the branch of Adeona japonica (ORTMANN), $5.5 \mathrm{~cm}$ in height. Width of the branches, $4-6 \mathrm{~mm}$.

\section{Alcyonidium sagamianum sp. nov.}

(Pl. X, Fig. 3, Pl. XI, Figs. 1-3; Text-fig. 2)

Zoarium: The zoarium is erect, columnar, branching, large and prominent. It is brownish or grayish in spirit, but the life colour is noted by the collector as cinnamon rufous in general and apricot orange at each tip of branch and attaching base. It stands upright from the unilaminar encrusting base spreading over a stone. The basal part of the upright stem is somewhat constricted in diameter. The branches are small in number, somewhat more slender than the stem tapering gradually to the tips.

The colony is tough to the touch and coarse in appearance for its thickened, chitinous outer layer provided with numerous, crowded, minute mamillae densely distributing all over the surface. It gives something like a spongy feeling and presents distinct elasticity, both probably due to its kenozooecia 1 medullary structure.

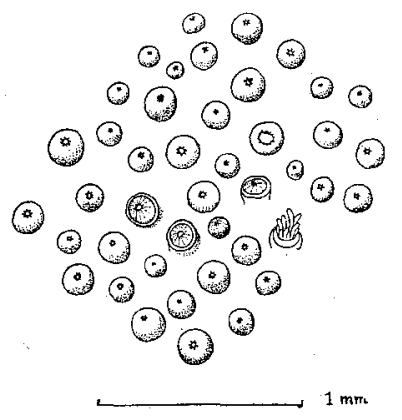

Fig. 2. Alcyonidium sagamianum sp. nov. Surface view of the colony. with crowded namillae.

Zooecia: The autozooecia are arranged in a peripheral layer, each disposing radially at right angles to the external surface. Each of them is slender and elongated, extending straight to some depths, or slightly oblique at its basal half. The zooecial orifice opens at the summit of the minute mamilla and the external interspaces between mamillae are filled with conspicuous thick layers. The vestibule and the atrium are distinct; the tentacles are stout, 20 in number. The alimentary canal is somewhat complicated and distinctly elongated.

Kenozooecia: The central part of the columnar branch is composed of many kenozooecia, arranged longitudinally or obliquely along the axis. The walls of them are conspicuously thickened and their cavities are usually empty in the axial part, and 
provided with brown bodies or degenerated tissues in the outer part of the medulla.

Remarks: The peculiar shape and colour of the zoarium will make easy to distinguish the present species from any of the other known species of Alcyonidium. It is more or less closely allied to Al. gelatinosum in its polylamellar colony with crowded frontal mamillae supporting zooecial apertures. The shorter zooecia, more closely distributed mamillae and soft and transparent nature of the zoarium are the distinguishing characteristics of $A l$. gelatinosum. In the allied form $A l$. verrilli, the zooecia are short and stout and situated obliquely to the surface, and the zooecial walls are clearly visible among mamillae. In comparing the photographs of OsBURN (1912, pl. 31, figs. 92, 92a) with those of the present species, one will be satisfied to the separation of these two species. Alcyonidium polypylum is another species developing into the cylindrical zoarium, but its cross section is quite different in showing much smaller and numerous partitions.

Specimen examined: No. 8316 (Biological Laboratory, Imperial Household, Coll. Bry. No. 35). 1 mile west of Kameki-shô, off Nagai, Kanagawa Prefecture. 54-55 m. January 14, 1933. Two complete colonies and several fragments. A colony is $12,5 \mathrm{~cm}$ in height, and its three branches are $7.5,7.2$ and $4.5 \mathrm{~cm}$ in length respectively. The largest diameter of the stem is $1.4 \mathrm{~cm}$ and that of the branches is $1.2 \mathrm{~cm}$. (Type) Another colony is $14.2 \mathrm{~cm}$ in height and $1.6 \mathrm{~cm}$ in maximum breadth, but with shorter branches.

\section{Alcyonidium kurilensis sp. nov.}

(Pl. X, Fig. 4, Pl. XI, Figs. 4-6)

Zoarium: The zoarium is erect, palmate or lobate, thick, tough and rough to the touch. The margin of the lobate body extends into several branches. The surface of the colony is thickly covered by innumerable number of short branched spines which emanate from distinct kenozooecia. The thickened branches are composed of two opposite layers of zooecia and rather thin kenozooecial medullary axis. Zooecial borders are difficult to observe in frontal view.

Zooecium: The zooecia are distinguished into two types, the larger and the smaller. The larger type of zooecia is arranged in two opposite layers separated by axial medullary layer, turning their proximal ends to each other. Their cavities are conspicuously large and sac-like, containing large polypides. The smaller type of zooecia is situated among the larger ones. Some of them are usually crowded at the lateral margin of the flattened zoarium, arranged in some radiating rows. They seem to be young, developing zooecia filling up the interspaces between the distal parts of the sac-like zooecia. These arrangements are shown in PI. XI, fig. 4., 
Kenozooecia: The thin median medullary layer of the branch is composed of a number of flattened kenozooecia, arranged longitudinally along the zoarial axis. Their walls are not much thickened. Sometimes one or two sac-like, oval kenozonecia containing an egg are observed among the medullary zooecia (Pl. XI, fig. 5).

Spines: Spines are numerous and small. Each of them extend from a peculiar small kenozooecium with no aperture. It is chitinous, hollow and filled with tissues. The end of the spine is usually divided into two or three branches.

Remarks: The circular orifice with no chitinized lips of this species is distinctly of Alcyonidium, but the chitinous hollow spines are commonly met with among the species of Flustrella. I am now inclined to place the present species in Alcyonidium because of the important character of its orifice.

The general appearance of the zoarium is close to $A l$. verrilli, but in that species the zooecial aperture opens on the distinct mamilla, and the zooecial borders are quite distinct in frontal view, and the spines are absent. The present species shows general resemblance to Flustrella vegae from Bering Sea, but differs clearly in the Alcyonidiumtype of its orifice, the branched, cervicorn spines, and the broader palmate zoarium.

Alcyonidium cervicornis from Alaska shows some resemblances to the present materials. It has similar apertures placed among numerous cervicorn spines emanating from smaller kenozooecia, but it differs in the zoarial characters and mamillated nature of the orifice.

Specimen examined: No. 4011. K. Kuronuma Coll. near Alaid Channel, Northern Kuril Is. $30-40$ fathoms. Several large fragments of a colony, without attaching base, $10 \sim 30 \mathrm{~mm}$ in breadth and $3 \sim 5 \mathrm{~mm}$ in thickness. (Type)

\section{Flustrella stolonifera (OKADA) 1921}

(P1. XII, Figs. 1-4; Text-fig. 3 A, B.)

Flustra stolonifera OKADA, 1921, Annot. Zool. Jap., 10, 3, p. 19, text-fig. 1a-e.

Zoarium: The colony is conspicuous, erect, branched, bilamellar, reddish brown or pale brown in preserved specimens. The numerous, flustroid shoots emanate from a flat, unilamellar, attaching base of considerable width spreading over the substratum. The grown-up colony gives a somewhat bushy appearance.

The spreading base is also composed of many divided lobes extending closely side by side. The branching is dichotomous. The surface of the branch is beautiful with regularly arranged zooecia, and distinct cervicorn spines scattered here and there on the flattened shoot.

Zooecia: The zooecia are arranged in two opposite layers and there is no medullary structure between the two layers. The zooecia are regularly elongate 
hexagonal or quadrangular, separated by rather thick walls clearly seen in frontal view. A pair of small, triangular spines are situated laterally to the zooecial aperture, and sometimes another pair of spines are observed situating a little proximally to the former, but no more spines of the same kind are observed on the zooecial borders. The large cervicorn spines emanate at the middle of the large kenozooecia which are almost the same size as the autozooecia. The aperture is transverse, slit-like with distinct chitinous proximal lip.

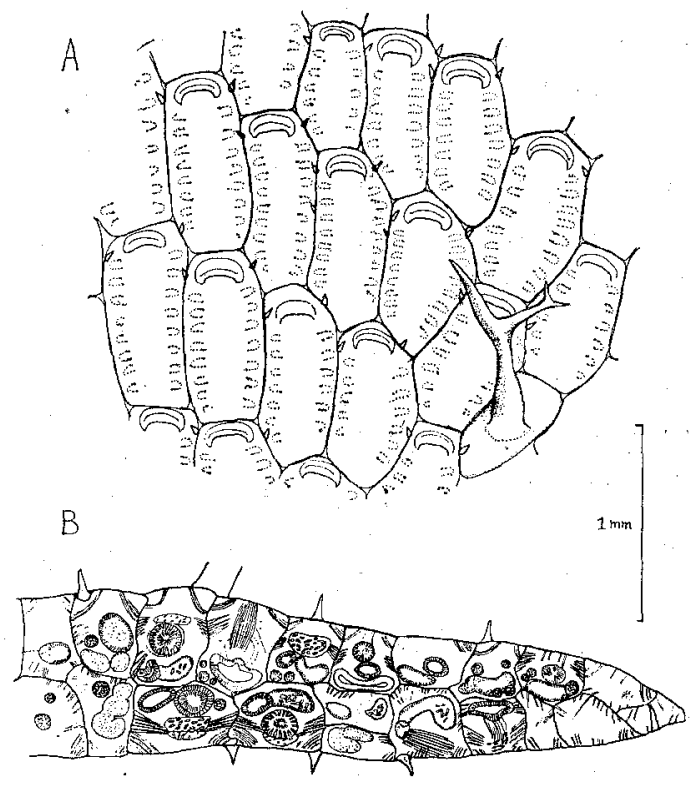

Fig. 3. Flustrella stolonifera (OKADA). A. Surface view of a stem. B. Transverse section of a branch.

Polypide: The polypide is large, with rather short and thick tentacle sheath situating obliquely in the rectangular zooecial cavity. The alimentary canal is somewhat developed. The coecum and intestine are conspicuously large and prominent. The parietal muscles extremely developed and often can be seen in frontal view.

The parieto-diaphragmatic muscles extremely developed.

Remarks: The species of Flustrella have long been known only in the encrusting form, and HARMER retained Elzerina with some doubt for erect branching forms. In 1947 SILËN described two new species of Flustrella with erect, branching zoarium from the "Vega" collection in 1879 in Bering Sea, which preserved in the State Museum of Natural History, Stockholm. Thus there seems remain no more reason to retain Elzerina, if it does not take another limitation. Both of SILÉN's species have some affinities with the present species. 
Fl. gigantea resembles in its large, distinct zooecia, cervicorn spines and branched colony but it is easily distinguished from the present species in the following characteristics:---(1) The colony is repeatedly bifurcated and branches are in one plane forming a fan. (2) autozooecia are not in immediate contact, but separated by a series of small kenozooecia, each bearing a tree-shaped spine.

$F$. vegae differs from the present form in having numerous single spines emanating from distinct kenozooecia surrounding the autozooecia.

The young, growing margin resembles much that of Flustrella hispida in having a small number of short spines, but the present form differs from that species in the zoarial structures, and the presence of the large cervicorn spines. Flustrella corniculata seems to be close to the specimens at hand, but the kenozooecia supporting the triangular spines are very conspicuous and larger than those of the present form. In my opinion there seems to be some confusions in the limitation of Fl. corniculata. I cannot share the opinion to include Alcyonidium cervicornis into Fl.corniculata. The former differs distinctly from the latter in having circular apertural fold, and large cervicorn spines emanating from distinct large kenozooecia, and no small, triangular spines of the different kind.

The present form was described by Y. OKADA under the name of Flustra stolonifera, as a member of the Flustridae, but, in my opinion, it belongs not to Cheilostomata but to Ctenostomata. He described the zooecia to be small, somewhat rounded, distinctly raised, but figured none of them. I could never find them in the fully developed individuals. The present species, therefore, is interesting to give an instance showing close affinities between the Cheilostomata and the Ctenostomata.

Specimen examined: No. 7745 (Biological laboratory, Imperial Household, Coll. Bry. No. 11). Hayama, Shore, July 23, 1929. A large bushy colony attached to the root of sea weed. The erect branch is $5-11 \mathrm{~cm}$ in height and $5-6 \mathrm{~mm}$ in breadth.

No. 7792 (Biological Laboratory, Imperial Household, Coll. Bry. No. 9). Hayama, Shore, July 14, 1.929. A bushy colony with short branches measuring only $1-3 \mathrm{~cm}$ in height and $3-5 \mathrm{~mm}$ in breadth.

\section{Flustrella stolonifera var. aspinosa var. nov.}

(P1. XII, Fig. 5.)

Zoarium: The zoarium is lobate or palmate, attaching to substratum by an expanded unilamellar base. The erect part is bilamellar, with distinctly bordered zooecia arranged in somewhat distinct series differing from the above-mentioned species. The colour of the zoarium in the preserved state shows dark brownish in formalin and pale grayish in spirit. 
Zooecia: The large cervicorn spines completely wanting. The aperture is narrow with thin lips.

Remarks: The present form is very close to Flustrella stolonifera, but the zoarial characters and the complete wanting of carvicorn spines seem to be enough to erect a new variety.

Specimen examined: No. 5418. MAWATARI Coll. Kurihama, Kanagawa Prefecture. Shore. August 12, 1945. A bushy colony, $2 \mathrm{~cm}$ in height.

No. 9037. Mawatari Coll. Jogashima, Kanagawa Prefecture. Shore. August 20, 1953. Numerous colonies attached to the holdfast of a seaweed, $2-4 \mathrm{~cm}$ in height. (Type)

\section{EXPLANATION OF PLATES X-XII}

\section{Plate X}

Fig. 1. Alcyonidum erectum SiLÉN. $\quad \times 1$

Fig. 2. Do. Another colony. $\quad \times 1$

Fig. 3. Alcyonidium sagamianum sp. nov. $\quad \times 1$

Fig. 4. Alcyonidium kurilensis sp. nov. $\quad \times 1$

\section{Plate XI}

Fig. 1. Alcyonidium sagamianum sp. nov.

Transverse section of tip of branch. $\quad \times 40$

Fig. 2. Do. Transverse section of stem. $\quad \times 40$

Fig. 3. Do. Transverse section of branch. $\quad \times 10$

Fig. 4. Alcyonidium kuriliensis sp. nov.

Transverse section of marginal part. $\quad \cdots 40$

Fig. 5. Do. Transverse section of median part. $\quad \times 40$

Fig. 6. Do. Transverse section of tip of branch. $\quad \times 20$

Fig. 7. Alcyonidium erectum SILÉN.

$\begin{array}{ll}\text { Transverse section. } & \vdots 20\end{array}$

\section{Plate XII}

Fig. 1. Flustrella stolonifera (OKADA).

Fig. 2. Do. Longitudinal hand section. $\quad \times 40$

Fig. 3. Do. Transverse section of tip of branch. $\quad \times 40$

Fig. 4. Do. Transverse section of stem. $\quad \times 40$

Fig. 5. Flustrella stolonifera var. aspinosa var. nov. $\quad \times 12$ 
Publ. Seto Mar. Biol. Lab., III, 2 (1953)

PLATE X
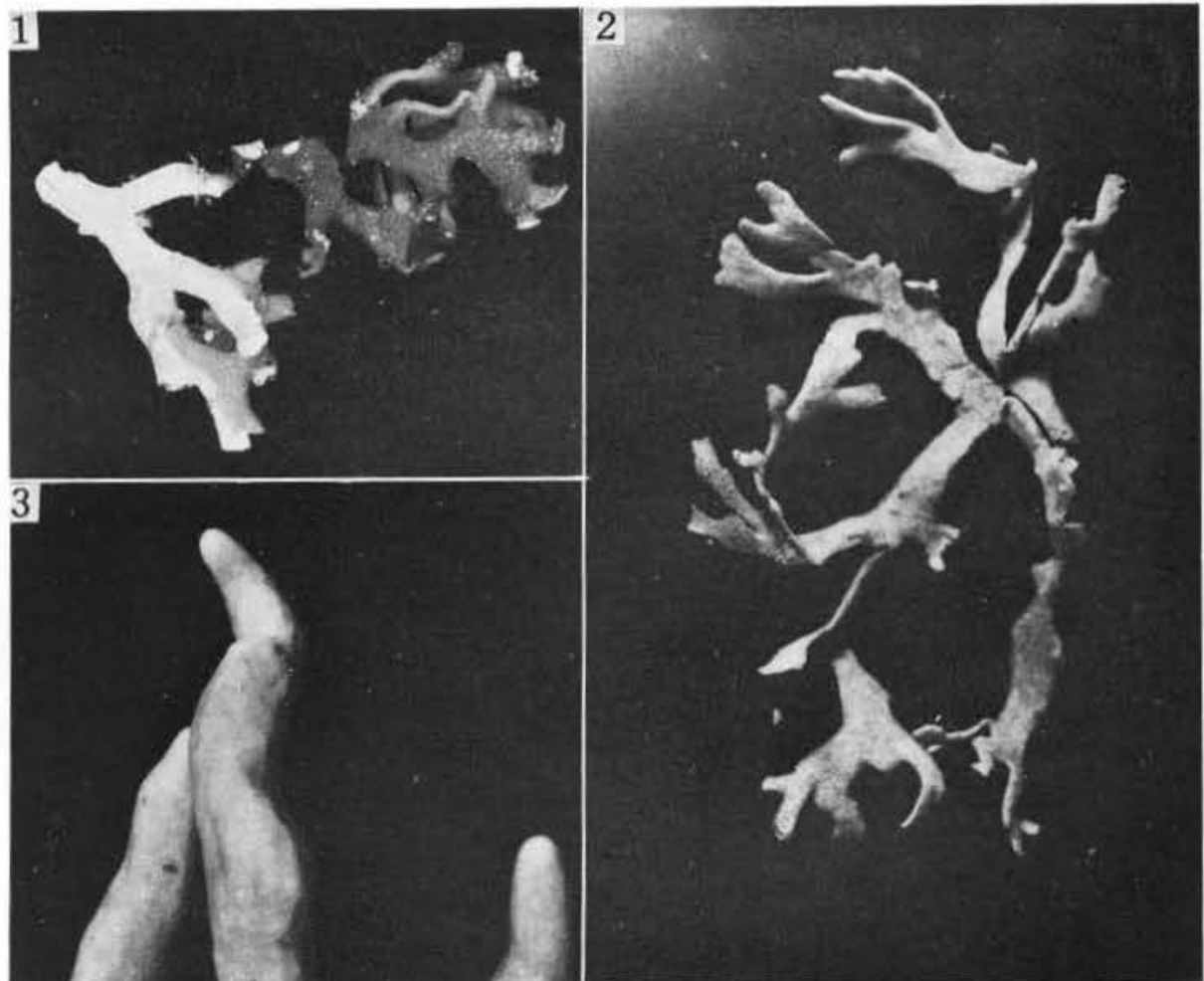

3
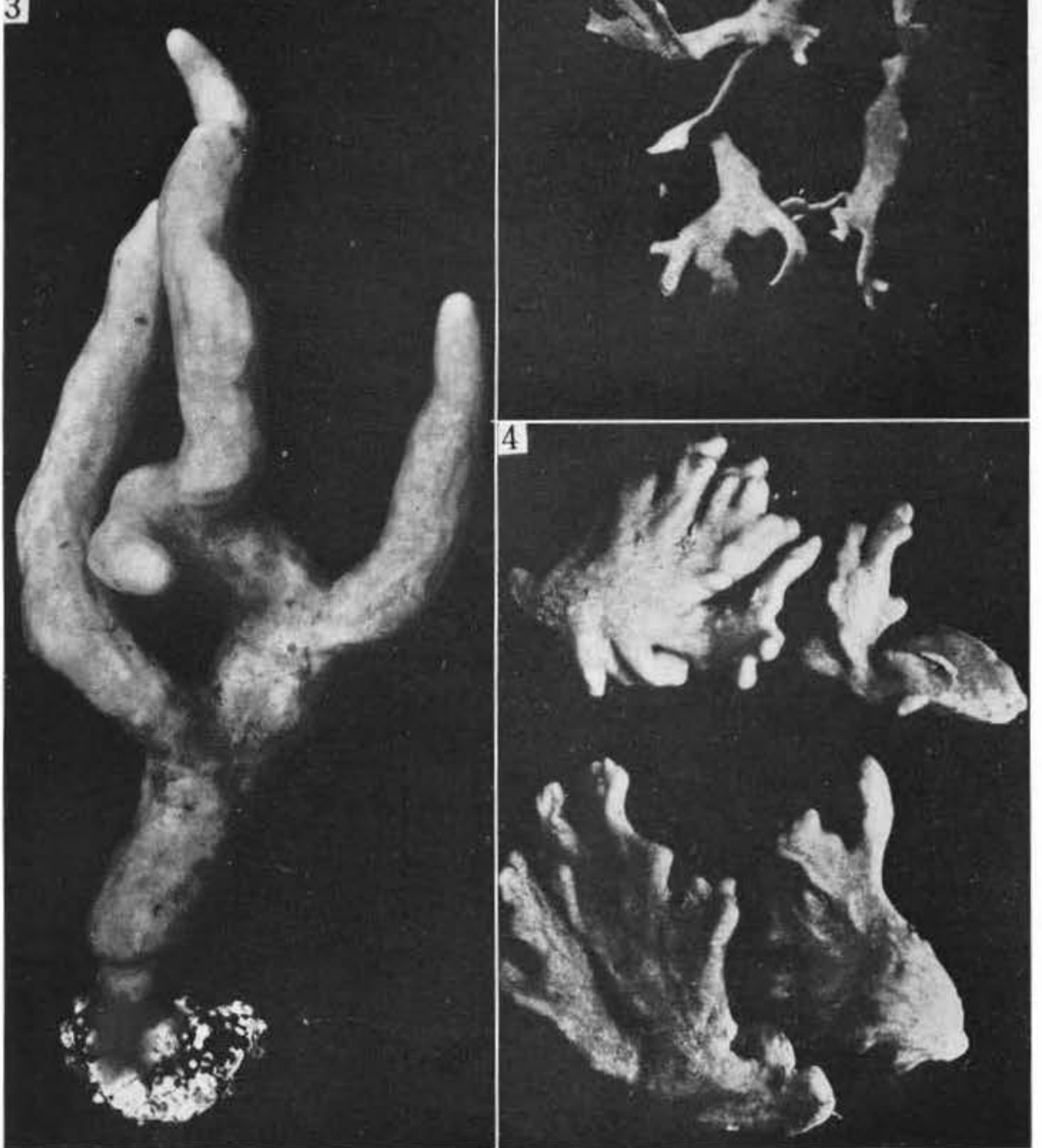

S. Mawatari: Studies on Japanese Ctenostomata. I. 
Publ. Seto Mar. Biol. Lab., III, 2 (1953) PLATE XI

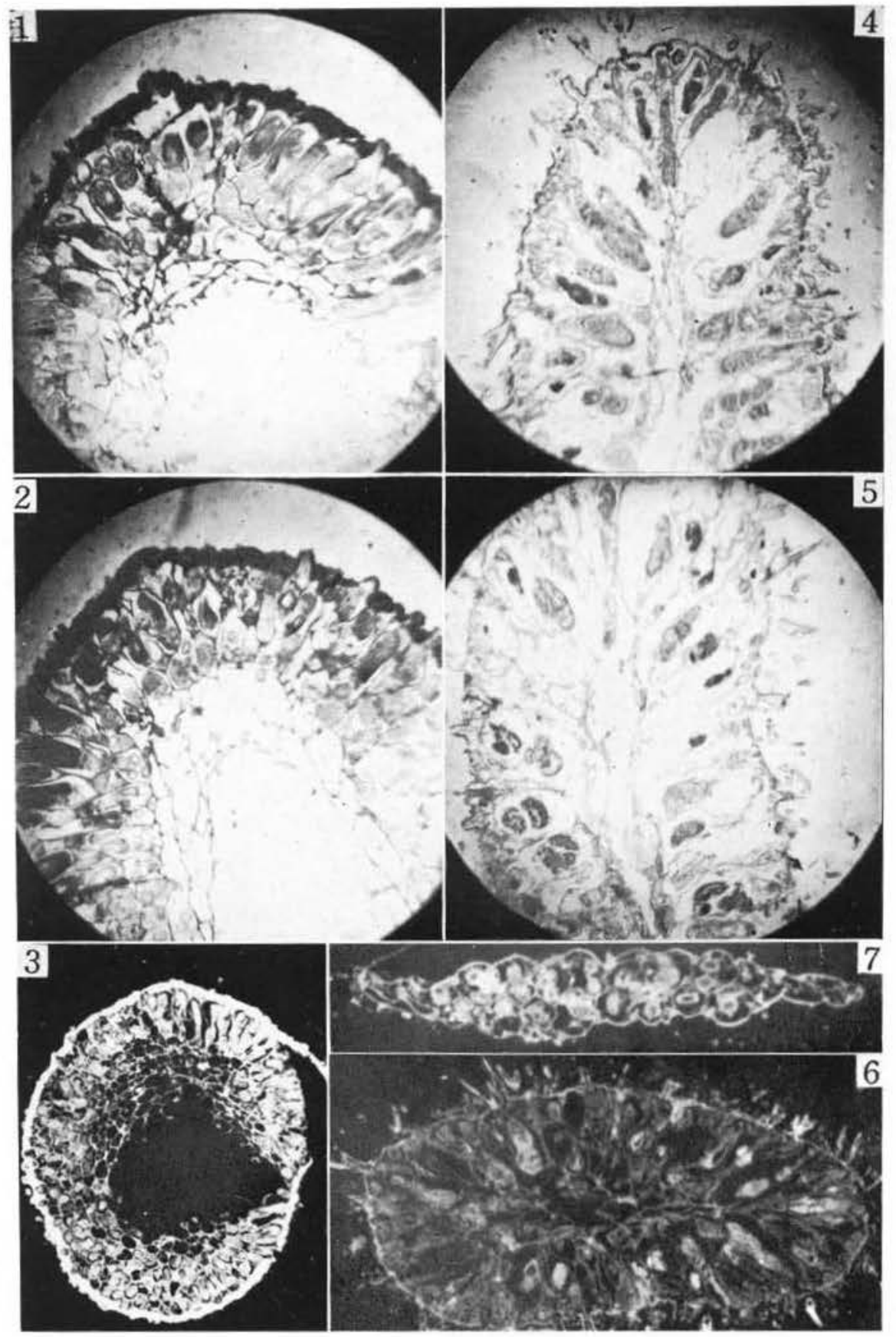

S. Mawatari: Studies on Japanese Ctenostomata. I. 
Publ. Seto Mar. Biol. Lab., III, 2 (1953)

PLATE XII

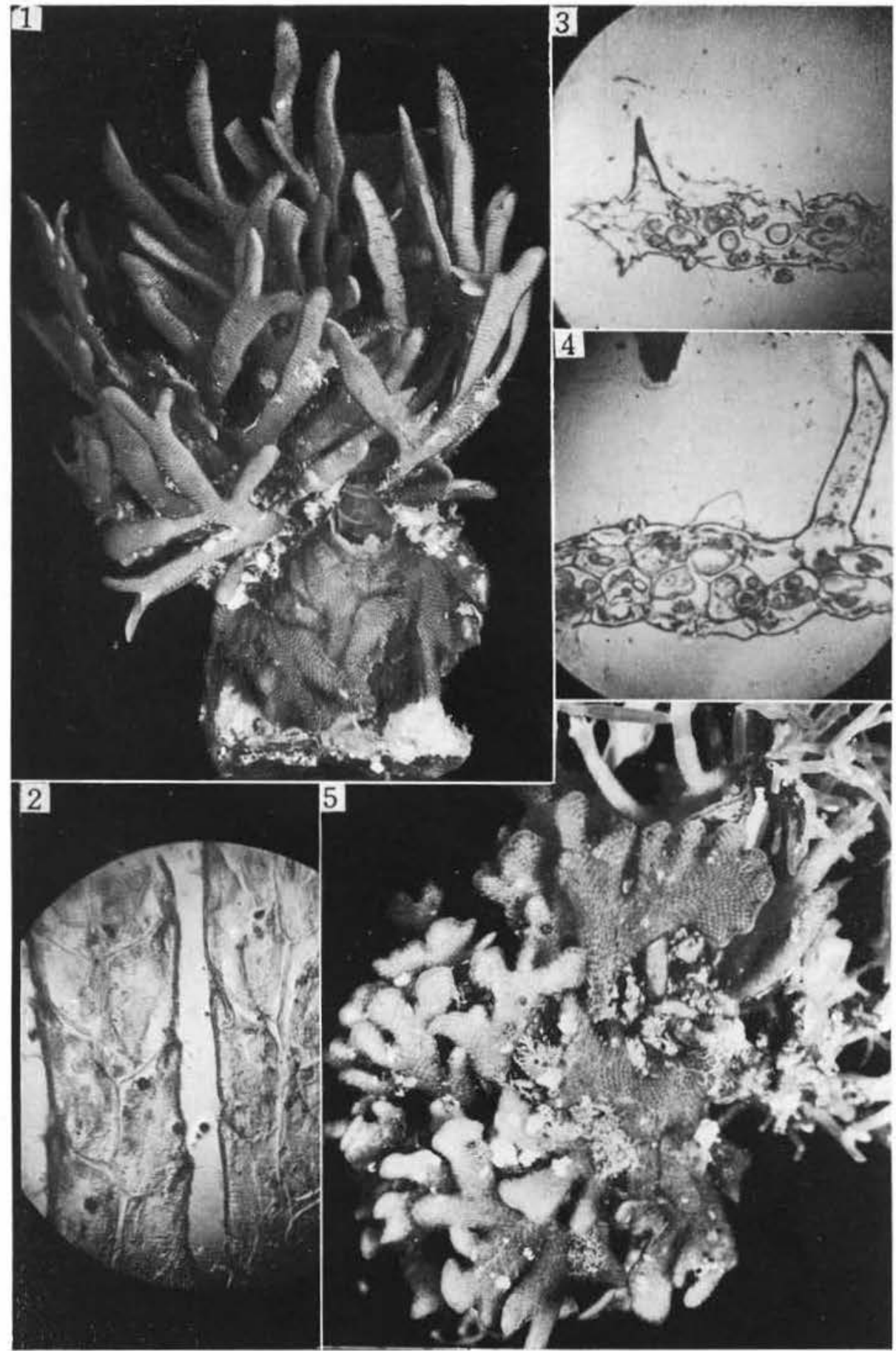

S. Mawatari : Studies on Japanese Ctenostomata. I. 